\title{
Genetic diversity analysis for various morphological and quality traits in bread wheat (Triticum aestivum L.)
}

\author{
Girnam Singh ${ }^{1}$, Pradeep Kumar ${ }^{2 *}$, Ravi Kumar ${ }^{1}$ and L. K. Gangwar ${ }^{1}$ \\ ${ }^{1}$ Sardar Vallabhbhai Patel University of Agriculture and Technology, Meerut-250110 (UP), INDIA \\ ${ }^{2}$ Indian Institute of Wheat and Barley Research, Karnal-132001 (Haryana), INDIA \\ *Corresponding author. E-mail:pradeeptaliyan231@gmail.com \\ Received: April 30, 2017; Revised received: July 29, 2017; Accepted: January 5, 2018
}

\begin{abstract}
The present investigation was carried out during 2011-12 in a randomized block design (RBD) with 35 diverse wheat genotypes to assess the genetic diversity for various morphological and quality traits. The analysis of variance for grain yield and its contributing components namely days to $50 \%$ flowering, days to maturity, productive tillers, plant height, spike length, spikelets pet spike, grains per spikelet, biological yield, harvest index, 1000 grain weight, grain yield and gluten content showed highly significant differences (at $<1 \%$ level of significance) among the genotypes under present study. High heritability along with high genetic advance and high phenotypic coefficient of variation (PCV) and genotypic coefficient of variation (GCV) for grain yield (g), biological yield (g), harvest index (\%), spike length $(\mathrm{cm})$ and 1000 grain weight $(\mathrm{g})$ indicated substantial contribution of additive gene action in the expression and thus selection would be effective for genetic improvement of these traits for improving grain yield in wheat. On the basis of multivariate analysis, 35 genotypes were grouped into ' 6 ' clusters based on genetic divergence $\left(D^{2}\right)$ value. The compositions of clusters revealed that the Cluster IV contained the highest number of genotypes (9) followed by Cluster II (8), Cluster VI (8) and Cluster III (7). The highest inter cluster values were recorded between cluster III and V (8357.19) followed by cluster IV and V (7513.88), cluster IV and VI (6009.44) and cluster III and VI $(5530.40)$ exhibiting wide genetic diversity. Among different traits, biological yield (32.12\%), productive tillers $(28.74 \%)$, harvest index $(26.71 \%)$, plant height $(24.20 \%)$, grain yield $(19.23 \%)$ and grains per spikelets $(14.89 \%)$ had maximum contribution to total genetic divergence, therefore may be used as selection parameters in transgressive segregants. Selection of genotypes from the clusters may be used as potential donors for further hybridization programme to develop genotypes with high yield potential in wheat crop.
\end{abstract}

Keywords: Bread wheat, Genetic diversity, Genetic parameters, Gluten content, Yield traits

\section{INTRODUCTION}

Bread wheat (Triticum aestivum L.) is the second most important cereal crop of India and plays a vital role in food and nutritional security. About nearly 55 percent of the world population depends on wheat for about 20 percent of calories intake (Anonymous 2016). India holds second position in both area and production after china and second most important crop planted to an area of 30.23 million hectares with production amounting to 93.50 million tons (Anonymous 2016). To feed the growing population, the country wheat requirement by 2030 has been estimated at 100 million metric tons and hence, there is an immediate need to increase wheat production to achieve this target (Sharma et al., 2011). This can be achieved by enhancing the production of wheat by developing improved varieties through heterosis breeding among parents having high genetic divergence. The main objective of any plant breeding programme is to develop cultivars of high yield potential with acceptable quality. The knowledge of genetic variability for yield and its contributing components helps in the improvement of grain yield and planning of effective breeding programme. The creation and utilization of genetic diversity is essential to overcome the problems of narrow genetic base and also to generating precise information on the nature and degree of genetic diversity in selecting the parents for targeted hybridization. The cluster analysis is an appropriate method for determining family relationship i.e. to determine the extent of genetic distance of genotypes from each other. Therefore, information on the genetic diversity for grain yield is important to meet the diversified goal of plant breeding such as breeding for increasing yield, wide adaptation and desirable quality traits (Lal et al., 2009). A wide range of genetic variability present in the material under study provides chances for selection of desired plant types. Therefore this experiment was conducted to identify genetically divergent wheat genotypes as donors, with desirable traits for hybridization for grain yield and other yield contributing components in wheat crop. 


\section{MATERIALS AND METHODS}

The experimental material comprised 35 diverse genotypes of wheat were evaluated in a randomized block design (RBD) with three replications during 2011-12 at Crop Research Centre, Sardar Vallabhbhai Patel University of Agriculture and Technology, Meerut (U.P.). Plot size was kept as four rows of $3.0 \mathrm{~m}$ length with row to row distance of $23 \mathrm{~cm}$ and plant to plant distance of $10 \mathrm{~cm}$. All the recommended agronomical practices (irrigation at all critical stage, dose of fertilizers) were adopted to raise the normal crop. Observation were recorded on five randomly selected plants in each replications for days to $50 \%$ flowering, days to maturity, number of productive tillers per plant, plant height $(\mathrm{cm})$, spike length $(\mathrm{cm})$, number of grains per spikelet, number of spikelets per spike, biological yield per plant $(\mathrm{g})$, harvest index $(\%)$, grain yield per plant (g), 1000 grain weight (g) and gluten content $(\%)$. The mean values from each replication were subjected to statistical analysis using SAS and CROPSTAT (commercial version) computer software. The analysis of variance (ANOVA) was done based on the method suggested by Panse and Sukhatme (1969). The PCV and GCV were calculated by the formula suggested by Burton and De Vane (1953). Heritability and genetic advance as percent of means for each character was calculated following formula as suggested by Johnson et al. (1955). Also, data were subjected to nonhierarchal Euclidean cluster statistic (Spark, 1973). The genetic diversity was done through cluster analysis using $\mathrm{D}^{2}$ statistics suggested by Mahalanobis (1936) and they were grouped into five clusters based on $\mathrm{D}^{2}$ value using Tochers method suggested by Rao, (1952).

\section{RESULTS AND DISCUSSION}

Analysis of variance: The analysis of variance (ANOVA) indicated highly significant differences among the genotypes for days to $50 \%$ flowering, days to maturity, productive tillers, plant height, spike length, number of spikelets pet spike, number of grains per spikelet, biological yield, harvest index, 1000 grain weight, grain yield and gluten content (Table 1) reveal- ing the existence of sufficient genetic variability in the present set of breeding materials for all the traits under study. The characters which have sufficient genetic variability suggested that a crossing programme involving diverse genotypes may lead to an overall improvement in wheat crop. Significant differences among the genotypes for different morphological and quality traits were also earlier reported by Singh et al. (2013), Singh et al. (2014), Tewari et al. (2015), and Kumar et al. (2016a) in wheat crop.

Genotypic and phenotypic variability: The phenotypic coefficient of variation (PCV) was slightly higher than their corresponding genotypic coefficient of variation (GCV) for all the morphological and quality traits among the genotypes indicated that the characters were less influenced by the environment, therefore selection on the basis of phenotype alone can be effective for the improvement of these traits (Table 2). Higher values of PCV and GCV indicated that there was high variability exiting among the genotypes. The higher values of phenotypic coefficient of variation (PCV) and genotypic coefficient of variation $(\mathrm{GCV})$ were recorded for biological yield $(\mathrm{PCV}=28.57 \%$ and $\mathrm{GCV}=82.42 \%)$ followed by spike length (PCV=27.32\% and $\mathrm{GCV}=26.96 \%), 1000$ grain weight $(\mathrm{PCV}=26.09 \%$ and $\mathrm{GCV}=26.03 \%)$, grain yield $(\mathrm{PCV}=25.36 \%$ and $\mathrm{GCV}=25.18 \%)$, harvest index $(\mathrm{PCV}=22.35 \%$ and $\mathrm{GCV}=21.14 \%$ ), number of productive tillers per plant $(\mathrm{PCV}=18.65 \%$ and $\mathrm{GCV}=16.34 \%)$, number of grains per spikelet $(\mathrm{PCV}=17.09 \%$ and $\mathrm{GCV}=15.67 \%)$ and plant height $(\mathrm{PCV}=10.17 \%$ \& $\mathrm{GCV}=10.14 \%)$ indicating better opportunity for improvement in these traits through selection. A range of PCV (1.98 to 33.03\%) and GCV $(1.75 \%$ to $32.03 \%)$ were reported by Verma et al. (2014) whereas a range of PCV $(0.81 \%$ to $9.07 \%)$ and $\mathrm{GCV}(0.50 \%$ to $8.08 \%)$ reported by $\mathrm{Ku}-$ mar et al. (2017). The other researchers namely Singh et al. (2013), Singh et al. (2014) and Kumar et al. (2016a) also reported high value of PCV and GCV for grain yield and tillers per plant in wheat crop at different location of India. High phenotypic and genotypic coefficient of variation for grain yield, harvest index and tillers per plant were also reported by Kumar et al. (2016a) in wheat. A close examination of phenotypic

Table 1. Analysis of variance (ANOVA) for 12 morphological and quality traits in bread wheat.

\begin{tabular}{llll}
\hline Character & Replication $(\mathbf{d} \mathbf{f}=\mathbf{2})$ & Treatments $(\mathbf{d} \mathbf{f}=\mathbf{3 4})$ & Error $(\mathbf{d} \mathbf{f}=\mathbf{5 8})$ \\
\hline Days to maturity & 11.92 & $358.66^{* *}$ & 7.65 \\
Days to 50 \% flowering & 0.30 & $165.01^{* *}$ & 7.43 \\
Plant height & 0.10 & $249.08^{* *}$ & 0.52 \\
Productive tillers & 0.53 & $2.96^{* *}$ & 0.89 \\
Spike length & 0.09 & $1.89^{* *}$ & 0.06 \\
Spikelets per spike & 0.48 & $7.48^{* *}$ & 0.22 \\
Grains per spikelet & 0.01 & $0.12^{* *}$ & 0.02 \\
1000 grain weight & 0.04 & $17.80^{* *}$ & 0.13 \\
Harvest index & 18.25 & $72.71^{* *}$ & 5.17 \\
Biological yield & 10.13 & $114.28^{* *}$ & 15.62 \\
Gluten content & 0.01 & $1.31^{* *}$ & 0.02 \\
Grain yield & 8.45 & $27.61^{* *}$ & 3.49 \\
\hline
\end{tabular}


Girnam Singh et al. / J. Appl. \& Nat. Sci. 10 (1): 24 - 29 (2018)

Table 2. Estimates of genetic parameters for 12 morphological and quality traits in bread wheat.

\begin{tabular}{llcccccc}
\hline \multirow{2}{*}{ Character } & \multirow{2}{*}{ Mean } & \multicolumn{2}{c}{ Range } & \multirow{2}{*}{$\begin{array}{c}\text { Heritability } \\
\text { (broad sense) }\end{array}$} & \multirow{2}{*}{ GCV } & PCV & $\begin{array}{c}\text { Genetic advance } \\
\text { as \% of mean }\end{array}$ \\
\cline { 3 - 4 } & & Minimum & Maximum & & & 16.54 \\
Days to 50\% flowering & 84.50 & 74.33 & 97.67 & 87.60 & 8.58 & 9.16 & 17.14 \\
Days to maturity & 125.93 & 113.00 & 140.33 & 93.86 & 8.59 & 8.87 & 20.81 \\
Plant height & 89.80 & 73.87 & 108.87 & 99.37 & 10.14 & 10.17 & 16.83 \\
Productive tillers & 6.74 & 4.58 & 9.03 & 43.80 & 16.34 & 18.65 & 23.66 \\
Spike length & 11.19 & 9.13 & 13.13 & 90.58 & 26.96 & 27.32 & 17.27 \\
Spikelets per spike & 17.78 & 14.53 & 20.80 & 91.73 & 8.76 & 9.14 & 9.34 \\
Grains per spikelet & 3.30 & 2.93 & 3.87 & 63.96 & 15.67 & 17.09 & 22.27 \\
1000 grain weight & 40.27 & 34.46 & 45.83 & 97.77 & 26.03 & 26.09 & 20.69 \\
Harvest index & 42.60 & 30.79 & 56.66 & 81.32 & 21.14 & 22.35 & 15.68 \\
Gluten content & 8.69 & 7.04 & 9.72 & 99.86 & 6.93 & 7.62 & 30.94 \\
Biological yield & 31.44 & 20.30 & 46.67 & 97.80 & 28.24 & 28.57 & 36.44 \\
Grain yield & 13.39 & 9.50 & 20.66 & 69.73 & 25.18 & 25.36 & \\
\hline
\end{tabular}

Table 3. Distribution pattern of 35 genotypes of wheat into ' 6 ' clusters based on non-hierarchal Euclidean cluster analysis.

\begin{tabular}{|c|c|c|}
\hline Clusters & Genotypes & Name of genotypes \\
\hline I & 2 & WHEAR//2*PRL/2*PAS-TOR, FRET*2/4/SNI/TRAP\#3/KAUZ*2/TR AP///KAUZ/5/. \\
\hline II & 8 & $\begin{array}{l}\text { MUNAL\#1, WHEAR//2*PRL/2*PASTOR, MARCHOUCH*/SAADA/3/2*FRET2/KUKUNA// } \\
\text { FRET2, WAXWING/6/PVN// CAR422/AN A/5/BOW/CROW//BUC/, ATTILA*2//CHIL/ } \\
\text { BUC*2/3/KUKUNA, KAUZ//ALTAR84/AOS/3/MILAN/KAUZ/4/HUITES/7/, ATTI LA/3 / } \\
\text { *BCN//BAV92/3/TILHI/5/BAV92/3/PR, ROLF07/YANAC//TAUPETOF2001/BRAMBLI NG. } \\
\text { PRL/2*PASTOR,INQALAB91*2/TUKURU//WHEAR,WBLL1/KUKUNA//TACUPETOF2001/5/ }\end{array}$ \\
\hline III & 7 & $\begin{array}{l}\text { WAXWING/4/, KAUZ//AL TAR } 84 / \text { AOS/3/MILAN/KA UZ/7/CAL/NH//, WBLL*2/VIVITSI/4/ } \\
\text { D67.2/P66.270//,WAXWING/WHEAR//WAXWING/KIRITATI,PBW343*2/KUKUNA*2// } \\
\text { YANAC. }\end{array}$ \\
\hline & & $\begin{array}{l}\text { PBW343, ROELFS F2007, WBLL1//UP2338*2/VINITSI, FRET2*2/4/SNI/TRAP\#1/3/KAUZ*2/ } \\
\text { TRAP//KAUZ/5/,CAL/NH/H567.71/3/SERI/4/CAL/NH//H567.71/5/,ROLF07/YANAC/ }\end{array}$ \\
\hline IV & 9 & $\begin{array}{l}\text { TACUPETO F2001/BRA MB LING, FRET2/KUKU NA//FRET2/3P ARUS/ 5/FRET2*2/4/SNI/, } \\
\text { FRET2/KUKUNA//FRET2/3YANAC/4/FRET2 } 2 / 4 / \text { KIRITATI,WBLL } 1 * 2 / K U K U N A * 2 / / \\
\text { WHEAE. }\end{array}$ \\
\hline $\mathrm{V}$ & 1 & FRET*2/4/SNI/TRAP\#/3/KAUZ*2/TRAP///KAU/5/. \\
\hline VI & 8 & $\begin{array}{l}\text { TACUPETOF2001/BRAMBLING//KIRITATI, OLF07/YANAC//TAUPETOF2001/BRAMBLI } \\
\text { NG, ROLF07*2/KIRITAI, FRET*22/4SNI/TRAP\#1/3/KAUZ*2/TRAP///KAUZ*2/, FRET2/ } \\
\text { KUKUNA//FRET2/3PASTOR//HXL7573/2*BAU/, TRCH/SRTU/5/ KAUZ//A LTAR84/AOA/3/ } \\
\text { MILAN/KAUZ/, PBW343*2/KUKUNA//PARUS/3/PBW343*2/KUKUNA, PBW343*2/KUKUN } \\
\text { A//PARUS/3/ PBW3 } 43 * 2 / K U K U N A ~\end{array}$ \\
\hline
\end{tabular}

Table 4. Average inter and intra cluster distances among ' 6 ' clusters for 35 wheat genotypes.

\begin{tabular}{lllllll}
\hline Cluster & I & II & III & IV & V & VI \\
\hline I & $\mathbf{3 8 2 . 2 6}$ & 905.86 & 1841.64 & 1295.53 & 3450.59 & 2668.91 \\
II & & $\mathbf{4 7 3 . 5 8}$ & 1334.14 & 2087.89 & 4159.19 & 2155.33 \\
III & & & $\mathbf{4 3 7 . 0 6}$ & 1244.92 & 8357.19 & 5530.40 \\
IV & & & & $\mathbf{2 6 3 . 4 9}$ & 7513.88 & 6009.44 \\
V & & & & & $\mathbf{1 0 4 7 . 8 8}$ & 1625.73 \\
VI & & & & & $\mathbf{7 3 8 . 3 4}$ \\
\hline
\end{tabular}

and genotypic coefficient of variation indicating better opportunity for improvement in grain yield based on the selection of above traits in wheat crop.

Estimates of heritability (broad sense) and genetic advance: The estimates of high heritability $(>60 \%)$ coupled with high genetic advance $(>20 \%)$ were recorded for plant height $\left(\mathrm{h}^{2}=99.37 \%\right.$ and $\left.\mathrm{GA}=20.81 \%\right)$, spike length $\left(\mathrm{h}^{2}=90.58 \%\right.$ and $\left.\mathrm{GA}=23.66 \%\right), 1000$ grain weight $\left(\mathrm{h}^{2}=97.77\right.$ and $\left.\mathrm{GA}=22.27 \%\right)$, harvest index $\left(\mathrm{h}^{2}=81.32\right.$ and $\left.\mathrm{GA}=20.69 \%\right)$, biological yield $\left(\mathrm{h}^{2}=97.80 \%\right.$ and $\left.\mathrm{GA}=30.94 \%\right)$ and grain yield $\left(\mathrm{h}^{2}=69.73 \%\right.$ and $\left.\mathrm{GA}=36.44 \%\right)$ whereas high heritability with moderate genetic advance were estimated for days to $50 \%$ flowering $\left(\mathrm{h}^{2}=87.60 \%\right.$ and $\left.\mathrm{GA}=16.54 \%\right)$, days to maturity $\left(\mathrm{h}^{2}=93.86 \%\right.$ and $\left.\mathrm{GA}=17.14 \%\right)$, spikelets per spike $\left(\mathrm{h}^{2}=91.73 \%\right.$ and $\left.\mathrm{GA}=17.27 \%\right)$ and gluten content $\left(\mathrm{h}^{2}=99.86 \%\right.$ and $\left.\mathrm{GA}=15.68 \%\right)$ in (Table 2). While, moderate heritability coupled with moderte genetic advance were recorded for productive tillers. Similar findings pertaining to high heritability along with high genetic advance were also earlier reported by Singh et al. (2013), Singh et al. (2014), Meena et al. (2014), and Kumar et al. (2016a) in wheat crop. High heritability along with high genetic advance and high coefficient of variability (PCV and GCV) for grain yield, biological yield, harvest index, spike length and 


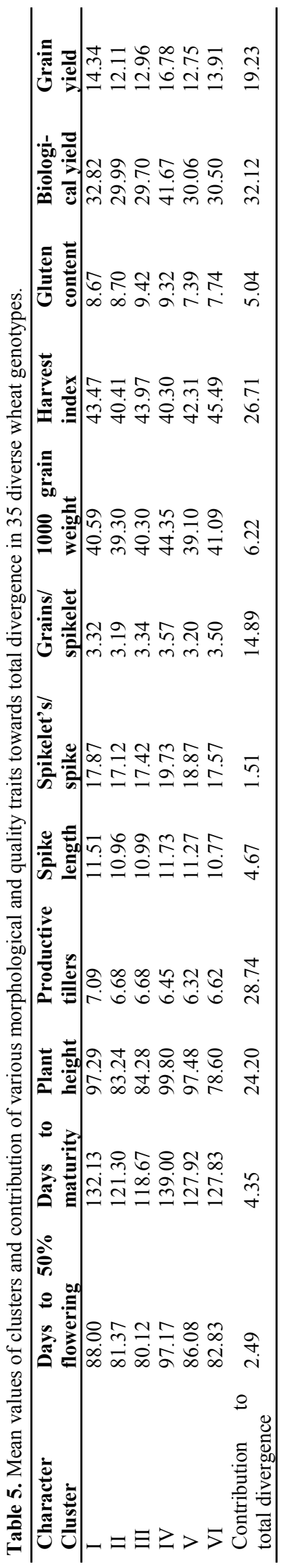

1000 grain weight exhibited good scope for improving these traits through selection. However, expression of traits viz; days to maturity and flowering, plant height, grains per spikelet and spikelets per spike that showed high heritability but moderate to low genetic advance and coefficient of variation whereas productive tillers showed moderate heritability, genetic advance and coefficient of variation, may be due to non-additive gene action therefore in such cases simple selection may not be very rewarding and hybridization followed by selecting desirable transgressive segregants would be the better option for improving these traits.

Genetic diversity analysis: The results of genetic diversity among 35 diverse wheat genotypes for various morphological and quality traits are presented in (Table 3 ). Based on the results of genetic diversity, 35 genotypes were grouped into six clusters by nonhierarchical Euclidean cluster statistics in such a way that the genotypes within a cluster had a small or low $\mathrm{D}^{2}$ values than those of in between the clusters. The compositions of cluster revealed that Cluster I (2), Cluster V (1), Cluster II (8), Cluster IV (9), Cluster III (7) and Cluster VI (8) had different number of genotypes. These results showed that number of genotype in different cluster as expected varied. The grouping of genotypes based on multivariate analysis has also been reported earlier by Singh et al. (2014), Verma et al. (2014), Tewari et al. (2015), Kumar et al. (2016b) and Vora et al. (2017).

The inter cluster distance was higher than the intra cluster distance indicating wide genetic diversity among the genotypes (Table 4). The inter cluster distance varied from 905.86 (cluster I \& II) to 8357.19 (cluster III \& V). The other notable inter cluster distance were recorded between cluster IV and V (7513.88), IV and VI (6009.44), III and VI (5530.40) which indicates that the genotypes involved in these clusters have wide genetic diversity and thus can be used in wheat hybridization programme for improving grain yield. The inter-cluster values that indicated close relationship were to be considered that hybridization among the genotypes of these clusters would not provide good levels of segregation. It is well recognized that greater the distance between clusters, wider the genetic diversity would be between the genotypes. Similar findings were also reported by Singh et al. (2014) and Verma et al. (2014). Therefore, highly divergent genotypes would produce a broad spectrum of segregation in the subsequent generations enabling further selection and improvement. The hybrids developed from the selected genotypes within the limit of compatibility of these clusters may produce desirable transgressive segregants of high magnitude of heterosis. This information would be very useful in planning wheat breeding programme particularly for improving grain yield in wheat crop. Verma et al., (2014), Tewari et al. (2015), Kumar et al. (2016b) and Vora et al. 
(2017) also reported similar findings on genetic diversity for different yield contributing components in wheat.

The maximum intra cluster distance was observed in clusters V (1047.88) followed by cluster VI (738.34), cluster II (473.58), and cluster III (437.06). The maximum intra cluster distance was mainly due to wide genetic diversity among the genotypes of these clusters. The maximum intra cluster distance was (13.96) by Verma et al. (2014), (391) by Kumar et al. (2016b), and (26.40) by Vora et al. (2017) reported in wheat crop. On the other hand, cluster IV (263.49) had minimum intra cluster distance indicating that compactness of clusters changed in different environments. The low genetic diversity and selection of parents within the cluster having higher mean values for a particular character may also be useful for further improving wheat genotypes for grain yield.

' 6 ' clusters showed considerable differences in mean value for different morphological and quality traits under present study (Table 5). Two genotypes of cluster-I were responsible for high cluster mean for productive tillers (7.09) and eight genotypes in cluster-III were responsible for high cluster mean for gluten content (9.42). Nine genotypes in cluster IV were responsible for high cluster mean for days to $50 \%$ flowering (97.17), days to maturity (139.00), plant height (99.80), spike length (11.73), number of spikelets per spike (19.73), number of grains per spikelet (3.57), 1000 grain weight (44.35), biological yield (41.67) and grain yield (16.78) while eight genotypes in cluster VI were responsible for harvest index. These were, thus adjudged to be considered suitable for creating maximum variability by hybridization and selecting the desired genotypes for higher grain yield. The contribution of the characters towards total divergence revealed that maximum percentage of contribution came from biological yield $(32.12 \%)$ followed by productive tillers $(28.74 \%)$, harvest index $(26.71 \%)$, plant height $(24.20 \%)$, grain yield $(19.23 \%)$ and number of grains per spikelets $(14.89 \%)$. The other traits namely days to $50 \%$ flowering, days to maturity, spike length, number of spikelets per spike, 1000 grain weight and gluten content had low percentage of contribution to total genetic divergence, therefore these traits may be used as selection parameters in segregating generations. Lal et al. (2009) also reported that grain yield, tillers per plant, plant height, spike length contributed maximum to genetic diversity.

\section{Conclusion}

Based on the above results may be concluded that analysis of variance (ANOVA) exhibited significant differences among the genotypes for all morphological and quality traits estimated under present study. The traits which have sufficient variability suggested that hybridization programme involving these diverse gen- otypes may lead to transgressive segregants and thus an overall genetic improvement in wheat crop. Inter and intra cluster distance indicated sufficient genetic diversity between and within clusters. It would be desirable to choose the donor from different clusters. The highest inter cluster distance was observed between cluster (III and V), cluster (IV and V), cluster (IV and VI) and cluster (III and VI) exhibiting wide genetic diversity and therefore could be useful in wheat hybridization programmes aiming high grain yield.

\section{REFERENCES}

Anonymous (2016). Progress Report of all India Coordinated Wheat and Barley Improvement Project, 1-5 pp G. P. Singh (Ed). Indian Institute of Wheat and Barley Research, Karnal.

Burton, G.W. and Vane de, E.H. (1953). Estimating heritability in tall fescue (Festuca arundinacea L.) from replicated clonal material. Agronomy Journal, 45: 478-481.

Johnson, H.W., Robinson, H.F. and Comstock, R. E. (1955). Estimates of genetic and environmental variability in soybeans. Agronomy Journal, 47: 314-318.

Kumar Pradeep, Singh Gyanendra, Kumar Sarvan, Kumar Anuj and Ojha Ashish. (2016a). Genetic analysis of grain yield and its contributing traits for their implications in improvement of bread wheat cultivars. Journal of Applied and Natural Science, 8: 350 -357.

Kumar Sandeep, Pradeep Kumar and Kerkhi, S.A. (2017). Genetic analysis for various yield components and gluten content in bread wheat (Triticum aestivum L.). Journal of Applied and Natural Science, 9(2): 879-882.

Kumar, J., Kumar, A., Singh, S.K., Singh, L., Kumar, A., Chaudhary, M., Kumar, S. and Singh, S.K. (2016b). Principal component analysis for yield and its contributing traits in bread wheat (Triticum aestivum) genotypes under late. Current Advances in Agricultural Sciences, 8: 55-57.

Lal, B.K., Ruchig, M. and Upadhyay, A. (2009). Genetic variability, diversity and association of quantitative traits with grain yield in bread wheat (Triticum aestivum L.). Asian Journal of Agricultural Sciences, 1 (1):4-6.

Mahalanobis, P.C. (1936). On the generalized distance on statistics, a statistical study of Chinese head measurement. Journal of the Asiatic Society of Bengal, (25): 301-307.

Meena, H.S., Kumar, D. and Prasad, S.R. (2014). Genetic variability and character association in bread wheat (Triticum aestivum). Indian Journal of Agricultural Sciences, 84 (4): 487-91.

Panse VG and PV Sukhatme (1969) Statistical Methods of Agricultural Workers. $2^{\text {nd }}$ Endorsement, ICAR Publication, New Delhi, India, pp: 381.

Rao, C.R. (1952). Advance statistical methods in biometrical research. John Wiley and Sons Inc. New York, p. 383.

Sharma, I., Shoran, J., Singh, G. and Tyagi, B. S. (2011). Wheat Improvement in India. Souvenir of 50th All India Wheat and Barley Research Workers, Meet, New Delhi. p 11.

Singh Gyanendra, Kulshreshtha, N., Singh, B.N., Setter, T.L., Singh, M.K., Saharan, M.S, Tyagi, B.S., Verma Ajay and Sharma, I. (2014). Germplasm characteriza- 
tion, association and clustering for salinity and waterlogging tolerance in bread wheat (Triticum aestivum). Indian Journal of Agricultural Sciences, 84: 1102-10.

Singh, M.K, Sharma, P.K, Tyagi, B.S. and Singh Gyanendra (2013). Genetic analysis for morphological traits and protein content in bread wheat (Triticum aestivum L.) under normal and heat stress environments. Indian Journal of Genetics and plant breeding, 73: 320-324.

Spark, D.N. (1973). Euclidean cluster analysis. Algorithm A. 58. Applied Statistics, (22): 126-130.

Tewari, R,, Jaiswal, J.P., Gangwar, R.P. and Singh, P.K. (2015). Genetic diversity analysis in Exotic germplasm accessions of Wheat (Triticum aestivum L.) by cluster analysis. Electronic Journal of Plant Breeding, 6: 11111117.

Verma, P.N., Singh, B.N., Singh, G., Singh, M.K. and Setter, T.L. (2014). Genetic diversity analysis for yield and other agronomic traits in bread wheat under water logged sodic soil condition. Journal of Wheat Research, 6: 51-58.

Vora, Z.N., Patel, J.B., Pansuriya, A.G. and Yusufzai, S.A. (2017). Genetic divergence analysis in bread wheat (Triticum aestivum L.). Research in Environments and Life Sciences, 10: 291-294. 